\title{
A Rare Cause of Upper Gastrointestinal Bleeding: Brunner's Gland Hamartoma
}

\author{
Üst Gastrointestinal Sistem Kanamasının Nadir Bir Nedeni: Brunner Bezi Hamartomu \\ ( ) Mehmet Uluşahin, • Etem Alhan, • Mehmet Arif Usta \\ Karadeniz Technical University Faculty of Medicine, Farabi Hospital, Department of General Surgery, Trabzon, Turkey
}

\begin{abstract}
Brunner's gland hamartoma is a submucosally localized and rarely encountered benign condition. Majority of cases are asymptomatic. Generally, it is diagnosed incidentally during endoscopic examinations of the upper gastrointestinal system (GIS) indicated for other reasons. It may sometimes present with symptoms of GIS bleeding or intestinal obstruction. In this paper, we present a 56-year-old female who was admitted to the emergency department with the complaints of nausea-vomiting and black-colored stool for two days. In upper GIS endoscopy, which was performed due to a pre-diagnosis of upper GIS bleeding, a submucosal mass was detected in the duodenum. The decision of surgery was taken for the patient who had an abdominal computed tomography demonstrating a duodenal mass. As a 4-cm polypoid mass was detected in duodenotomy performed after Kocher manoeuvre, mass excision was performed. The diagnosis of Brunner's gland hamartoma was established based on the pathological analysis of the surgical specimen. The patient, who had no problem, but atelectasis in the postoperative follow-up, was discharged on the postoperative day seven.
\end{abstract}

Keywords: Brunner's gland hamartoma, Brunner's gland hyperplasia, gastrointestinal bleeding, Brunner's gland, duodenum

\section{Öz}

Brunner bezi hamartomu submukozal yerleşimli olan, nadir görülen benign bir durumdur. Büyük çoğunluğu asemptomatiktir. Çoğu zaman başka nedenlerle yapılan üst gastrointestinal sistem (Gis) endoskopilerinde rastlantısal olarak tanı konulur. Bazen Gis kanaması ya da intestinal obstrüksiyon semptomları ile gelebilir. Biz bu yazıda bulantı, kusma ve iki gündür siyah renkli dışkı şikayeti ile acil servise başvuran 56 yaşında kadın hastayı sunduk. Hastaya üst GiS sistem kanaması ön tanısı ile yapılan üst Gis endoksopisinde duodenal submukozal kitle tespit edildi. Çekilen karın bilgisayarlı tomografisinde duodenal kitleden bahsedilen hastada operasyon kararı verildi. Kocher manevrası sonrası yapılan duodenotomide $4 \mathrm{~cm}$ 'lik polipoid kitle tespit edilmesi üzerine kitle eksizyonu yapıldı ve patolojisi Brunner bezi hamartomu olarak raporlandı. Postop takiplerinde atelektazi dışında problemi olmayan hasta postop yedinci gün taburcu edildi.

Anahtar Sözcükler: Brunner bezi hamartomu, Brunner bezi hiperplazisi, gastrointestinal kanama, Brunner bezi, duodenum

\section{Introduction}

Benign tumors of the duodenum are extremely rarely encountered (1). Although they are generally asymptomatic, they may cause symptoms of bleeding and obstruction. Brunner's gland hamartoma, which is one of the benign masses of the duodenum, originates from the Brunner's glands. Brunner's glands are structures located in the duodenal submucosa and secrete digestive enzymes and mucous. Brunner's gland hamartoma may be sessile or pedunculated. They are found frequently in the first part of the duodenum and rarely in the second part of the duodenum, and they are located more commonly on the posterior wall. It is believed that they do not exhibit malignant transformation.

\section{Case}

A 56-year-old female patient, who did not have any known additional problem, was admitted to the emergency department in another center with the complaints of small amount of hematemesis, nausea and
Address for Correspondence/Yazışma Adresi: Mehmet Uluşahin

Karadeniz Technical University Faculty of Medicine, Farabi Hospital, Department of General Surgery, Trabzon, Turkey

Phone: +90 5063713443 E-mail: ulusahinmehmet@hotmail.com ORCID ID: orcid.org/0000-0002-0212-2103 Received/Geliş Tarihi: 01 July 2017 Accepted/Kabul Tarihi: 02 October 2017
${ }^{1}$ Copyright 2018 by The Medical Bulletin of University of Health Sciences Haseki Training and Research Hospital
The Medical Bulletin of Haseki published by Galenos Yayinevi.

${ }^{\circledR}$ Telif Hakkı 2018 Sağlık Bilimleri Üniversitesi Haseki Eğitim ve Araştırma Hastanesi Haseki Tıp Bülteni, Galenos Yayınevi tarafindan basılmışıı. 
black-colored stool. It was learned that she had no such complaints previously. She denied recent weight loss, tobacco use, and alcohol or substance addiction. She did not have any history of a bleeding disorder or medication use. Abdominal examination was unremarkable, however, digital rectal examination revealed melena. Her pulse rate was $110 \mathrm{bpm}$ and blood pressure was $85 / 55 \mathrm{mmHg}$. The results of blood tests requested by the emergency department were as follows: hemoglobin: $6 \mathrm{~g} / \mathrm{dL}$, white blood cells: $9400 / \mathrm{mm}^{3}$ and thrombocyte: $370000 \mathrm{~mm}^{3}$. Due to the low level of haemoglobin, three units of blood were transfused. In upper gastrointestinal system (GIS) endoscopy, a submucosally localized mass was observed in the duodenum. No active bleeding was recognized. Abdominal computed tomography (CT) showed a 4-cm mass in the second part of the duodenum. The patient, who was admitted with GIS bleeding and whose haemoglobin value continued to decrease, was referred to our center. The CT scan taken in that center was re-evaluated by our

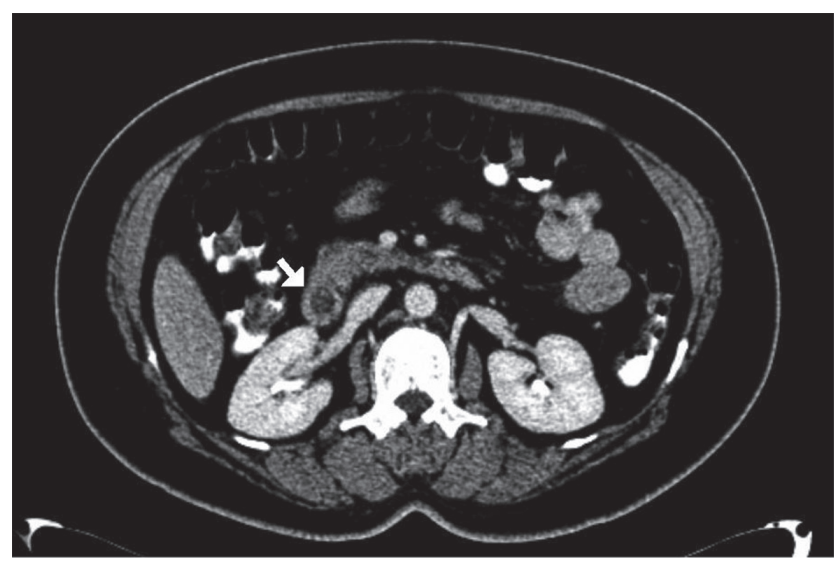

Figure 1. Axial, coronal and sagittal abdominal computed tomography scan showed duodenal mass in the second part of the duodenum (white arrows)

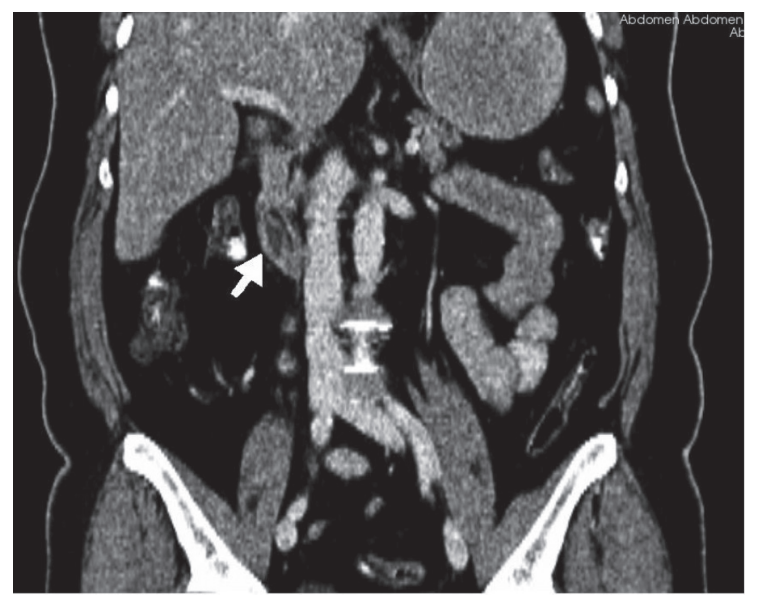

Figure 2. Axial, coronal and sagittal abdominal computed tomography scan showed duodenal mass in the second part of the duodenum (white arrows) radiology department and reported as 4-cm mass in the second part of the duodenum (Figure 1-3). Surgery was recommended for the patient. In laparotomy, the first and second parts of duodenum were released by Kocher maneuver. During exploration, a mobile mass which did not invade the surrounding structures was palpated in the second part of the duodenum. Duodenotomy was performed and the lumen was accessed. A pedunculated polypoid mass with the dimensions of approximately $4 \times 2 \times 2 \mathrm{~cm}$, which originated from the second part of the duodenum, was observed and excised with its peduncle included (Figure 4). Duodenotomy incision was closed as a Heineke-Mikulicz pyloroplasty. The patient, who had no problem, but atalectasis in the postoperative follow-up, was discharged without any problem on the postoperative day seven. The pathology was reported as Brunner's gland hamartoma. The patient attends outpatient follow-up visits in stable condition. Informed consent was obtained from the patient.

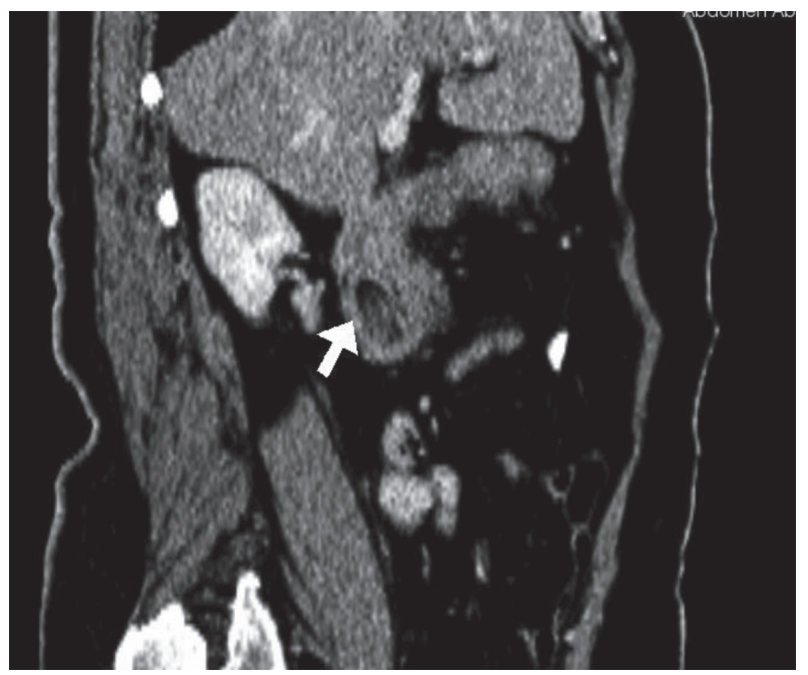

Figure 3. Axial, coronal and sagittal abdominal computed tomography scan showed duodenal mass in the second part of the duodenum (white arrows)

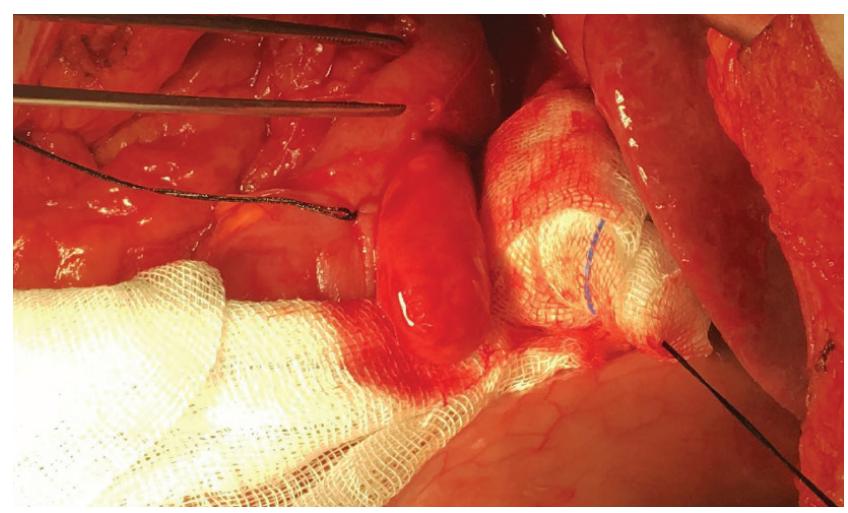

Figure 4. A polypoid mass detected in duodenotomy 


\section{Discussion}

Brunner's gland hamartoma is a rarely encountered submucosal lesion which was first described in 1835 (1). It accounts for approximately $5 \%$ of all duodenal tumors (2). It occurs more commonly in the age group of 40-60 years, although it may occur at any age and in any gender. There are pediatric cases in the literature $(3,4)$. They are generally pedunculated. Brunner's gland hyperplasia and hamartoma are pathologies originating from the Brunner's glands. The terms adenoma, brunneroma, and hamartoma have been used interchangeably with Brunner's gland hamartoma. Generally, those smaller than $1 \mathrm{~cm}$ are called hyperplasia and those larger than $1 \mathrm{~cm}$ are called hamartoma $(4,5)$. Although its diameters are generally below $1 \mathrm{~cm}$, there are also reported cases with diameters of up to $12 \mathrm{~cm}(5,6)$.

Definite pathogenesis remains unknown, however, there are publications suggesting that it may be associated with hyperacidity, inflammation and pancreatitis $(3,7,8)$. Generally, those with small dimensions progress asymptomatically and cause no symptoms $(7,8)$. They may be confronted incidentally in upper GIS endoscopy performed because of other reasons. It has been found that some patients, similarly to the patient represented in this article, may present with symptoms of GIS bleeding and intestinal obstruction, and such a case may be mortal (1). Especially in masses with large dimensions, pancreatitis and biliary obstruction related to pressure may develop and laboratory findings and symptoms specific for these clinical conditions may be confronted. Due to localization, large masses may be mistaken with pancreatic head carcinoma.

Differential diagnosis may include leiomyoma, gastrointestinal stromal tumor, neuroendocrine tumor, ectopic pancreas, and pancreatic head carcinomas $(5,6)$. Diagnosis of Brunner's gland hamartoma may be challenging. It may not be diagnostic most of the time even in cases where a biopsy is conducted due to observation of a submucosal lesion in upper GIS endoscopy (8). Endoscopic appearance may be mistaken with a pressing pancreatic mass or primary duodenal carcinomas, as it was in our patient. There are cases which could not be diagnosed preoperatively despite imaging methods, including endoscopy, barium tests and $\mathrm{CT}$, and were diagnosed with laparotomy (8). In centers having the opportunity, endoscopic ultrasonography may be a favorable diagnostic tool and may exclude other benign and malignant causes (9).

For Brunner's gland hyperplasias-hamartomas with small dimensions which are asymptomatic and incidentally confronted during endoscopy, conservative treatment is the best choice $(8,10)$. The best approach for symptomatic masses is surgical or endoscopic removal of the mass (10). Although endoscopy is a favorable option especially for pedunculated masses as it is non-invasive, it may be impossible to remove large masses by this method even for experienced endoscopists (8). For large masses, excision of the mass through duodenotomy, as it was performed for the patient represented in the article, seems as the best option. Isolated duodenal resections or pancreaticoduodenectomy may become necessary for these patients, though rarely. Its prognosis is favorable. It has been indicated in various resources that it has no potential for malignant degeneration.

In conclusion, Brunner's gland hamartomas are benign pathologies which generally have small dimensions and incidentally confronted in upper GIS endoscopies or imaging methods. Endoscopic or surgical excision is the best approach for symptomatic patient group. It may be life-saving for many patients to consider Brunner's gland hamartoma in patients presenting with GIS bleeding or intestinal obstruction.

\section{Authorship Contributions}

Surgical and Medical Practices: M.U., E.A., M.A.U. Concept: M.U., E.A., M.A.U. Design: M.U., E.A. Data Collection or Processing: M.U., M.A.U. Analysis or Interpretation: M.U., E.A. Literature Search: M.U., E.A., M.A.U. Writing: M.U.

Conflict of Interest: No conflict of interest was declared by the authors.

Financial Disclosure: The authors declared that this study has received no financial support

\section{References}

1. Mumtaz R, Shah IA, Ramirez FC. Brunner's gland hamartoma simulating a pancreatic mass with duodenal obstruction. Gastrointest Endosc 2002;56:932-4.

2. Kim K, Jang SJ, Song HJ, Yu E. Clinicopathologic characteristics and mucin expression in Brunner's gland proliferating lesions. Dig Dis Sci 2013;58:194-201.

3. Henderson L, Richards C, Willmott A, Dagash H. Brunner's gland hyperplasia causing gastric outlet obstruction in a 3-year-old child. Arch Dis Child 2017;102:231.

4. El Faleh I, Lutz N, Osterheld MC, Reinberg O, Nydegger A. Gastric outlet obstruction by Brunner's gland hyperplasia in an 8-year-old child. J Ped Surg 2009;44:e21-e4.

5. Iwamuro M, Tanaka T, Ando S, et al. Endoscopic Resection of a Pedunculated Brunner's Gland Hamartoma of the Duodenum. Case Rep Gastrointest Med 2016:6707235.

6. Malik AA, Wani ML, Malik RA, Irshad I. Brunner's gland hyperplasia: An unusual cause of gastrointestinal bleeding. Turk J Gastroenterol 2011;22:419-21.

7. Lu L, Li R, Zhang G, Zhao Z, Fu W, Li W. Brunner's gland adenoma of duodenum: report of twocases. Int J Clin Exp Pathol 2015;8:7565-9. 
8. Peloso A, Viganò J, Vanoli A, et al. Saving from unnecessary pancreaticoduodenectomy. Brunner's gland hamartoma: Case report on a rare duodenal lesion and exhaustive literature review. Ann Med Surg (Lond) 2017;17:43-9.

9. Patel ND, Levy AD, Mehrotra AK, Sobin LH. Brunner's gland hyperplasia and hamartoma: imaging features with clinicopathologic correlation. AJR Am J Roentgenol 2006;187:715-22.

10. Chattopadhyay P, Kundu AK, Bhattacharyya S, Bandyopadhyay A. Diffuse nodular hyperplasia of Brunner's gland presenting as upper gastrointestinal haemorrhage. Singapore Med J 2015;49:81-3. 